\title{
Performance and fatty acid profile of Holstein calves slaughtered at different weights
}

\section{Ana Maria Osorio Dias ${ }^{1}$ (iD, Luis Fernando Glasenapp de Menezes²* iD, Wagner Paris² (iD, Fabiana Luiza Matielo de Paula² (iD, Gean Rodrigo Schmitz² (iD, Saimon de Souza e Souza² (iD, Adriano Moreira Umezaki ${ }^{2}$ (D), João de Assis Farias Filho ${ }^{2}$}

\footnotetext{
${ }^{1}$ Universidade Federal de Santa Maria, Programa de Pós-graduação em Zootecnia, Santa Maria, RS, Brasil.

${ }^{2}$ Universidade Tecnológica Federal do Paraná, Programa de Pós-graduação em Zootecnia, Dois Vizinhos, PR, Brasil.
}

\begin{abstract}
Our objective was to evaluate performance and fatty acid contents of the meat of Holstein veal fed in feedlots and slaughtered at four different pre-determined live weights $(140,180,220$, and $260 \mathrm{~kg})$. Twenty-three non-castrated calves with initial average ages of 58 days and $57 \mathrm{~kg}$ live weight were used in this study. Average daily gain, dry matter intake, nutrient intake, cold carcass weight, cold carcass yield, scraps, and fat thickness improved with increasing slaughter weight. However, C18:0, C22:0, C18:2Trans10Cis12, C18:1n9Cis acids, sum of unsaturated fatty acids, and lipid content decreased with the increase in slaughter weight. Raising the slaughter weight of Holstein calves from 144 to $260 \mathrm{~kg}$ improves the performance of animals, mainly due to the increase in their intake capacity. However, this increase in slaughter weight does not result in significant changes in the fatty acid composition of the meat.
\end{abstract}

Key Words: feedlot, omega 3, omega 6, polyunsaturated fatty acids, weight gain

\section{Introduction}

Animal protein consumption is increasing both quantitatively and qualitatively. The consumer market values attributes such as palatability (tenderness, flavor, and juiciness), appearance (color, firmness, and marbling), convenience (cut or sliced product), and health and nutrition (protein, cholesterol, and other benefits) (Sobczuk-Szul et al., 2013). However, the consumption of red meat has been linked to the onset of cardiovascular diseases, hypertension, and obesity (Sobczuk-Szul et al., 2013). As a result, consumer interest in foods with desirable nutritional characteristics and health benefits has been rising. Beef calves may represent an alternative to red meat due to its low fat content ((Domaradzki et al., 2017). However, some research has suggested that the consumption of red meat is not a precursor to cardiovascular diseases, hypertension, and obesity, and does not raise the risk of cancer (Kim et al., 2016). Furthermore, beef has reasonable amounts of cis-9,trans-11 conjugated linoleic acid (CLA), which has anti-carcinogenic

Received: August 18, 2017

Accepted: April 5, 2018

*Corresponding author: luismenezes@utfpr.edu.br

Copyright (c) 2018 Sociedade Brasileira de Zootecnia. This is an Open Access article distributed under the terms of the Creative Commons Attribution License (http://creativecommons.org/licenses/by/4.0/), which permits unrestricted use, distribution, and reproduction in any medium, provided the original work is properly cited. effects (Griinari and Bauman, 2001). Although CLA is present in small quantities in meat products deriving from ruminants (1.7-10.8 $\mathrm{mg} \mathrm{CLA} / \mathrm{g}$ of fat in meat), its effects are highly significant for human nutrition (Wood et al., 2008) as well as in the formation of omega-3 fatty acids.

Sañudo et al. (2004) noted that breed and slaughter weights influenced carcass and meat quality parameters in several ways, including muscle structure and meat physiology. However, these authors worked with animals that were specifically bred for meat production and, thus, had relatively high slaughter weights, which calves do not.

Calves represent an alternative source of income to the dairy sector, and the use of these animals in feedlot allows a reduction in the age at slaughter and higher working capital within the cattle industry (Lopez-Campos et al., 2013). However, there is little information on the ideal live weight for slaughter of animals at this age, in terms of both performance and fatty acid profile of the meat. Thus, our objective was to analyze the performance and fatty acid profile of Holstein calves slaughtered at different live weights.

\section{Material and Methods}

Experiments were conducted in accordance with the ARRIVE guidelines and the UK Animals (Scientific Procedures) Act, 1986, other associated guidelines, and the EU Directive 2010/63/EU for animal experiments, 
and carried out in Dois Vizinhos, PR, Brazil (at latitude $25^{\circ} 42^{\prime} 52^{\prime \prime} \mathrm{S}$, longitude $53^{\circ} 03^{\prime} 94^{\prime \prime} \mathrm{W}$, and $519 \mathrm{~m}$ above sea level). Twenty-three non-castrated Holstein calves raised in feedlot, with an approximate starting age of $58 \pm 3$ days and an average live weight of $57 \pm 8 \mathrm{~kg}$, were randomly divided into four pre-stipulated slaughter weights $(140,180,220$, and $260 \mathrm{~kg}$ live weight).

Calves had a 15-day period to adapt to the facilities and employee management system. At weaning, the animals received an ADE vitamin injection, were dewormed with Albendazole, and weighed after a solid fast period of $16 \mathrm{~h}$. The animals were also vaccinated against clostridial diseases and foot-and-mouth disease according to the official calendar, then administered $1 \%$ ivermectin injections on the day of entry into the experiment to control parasitic infections, with additional administrations every 28 days during the weighing period. The animals were placed in individual pens and provided with a diet of corn silage as roughage and a concentrate commercial pellet containing $19 \%$ crude protein at a forage:concentrate ratio of 40:60. Calves were fed twice daily, with $50 \%$ of the feed provided at 09:00 $\mathrm{h}$ and the rest at 16:00 $\mathrm{h}$. A spare margin of $10 \%$ of the supplied nutrition was maintained, and the remains of the previous day weighed to estimate intake. Then, animals were weighed every 28 days after being subjected to fasting of solids and liquids for approximately $14 \mathrm{~h}$, thus providing the average daily weight gain (ADG) of the animal. The feed conversion of each animal was calculated by dividing measured daily intake of dry matter (DM) by ADG during the trial period.

The diet amount was calculated to allow approximately $10 \%$ as leftovers and was formulated based on nutritional requirements established by the NRC (2001) to generate an expected daily weight gain of $1.0 \mathrm{~kg}$ (Table 1). To determine the availability of each constituent, samples of concentrate and silage were weighed and put into a forced-air oven at $65{ }^{\circ} \mathrm{C}$ until they reached a constant weight. Crude protein (CP) content was evaluated via the Kjeldahl method (AOAC, 1995); neutral detergent fiber (NDF) and acid detergent fiber (ADF) were determined by the method described by Van Soest et al. (1991); and in vitro dry matter digestibility (IVDMD) was assessed using the approach described by Tilley and Terry (1963) to estimate dietary total digestible nutrients (TDN). Following this latter method, feeds were incubated in tubes containing $50 \mathrm{~mL}$ phosphate-buffered saline (final $\mathrm{pH} 6.69)$ prepared using a ratio of $4: 1(\mathrm{v}: \mathrm{v})$ of artificial saliva and rumen fluid. Two tubes containing only the buffered solution ("blank run") and two tubes with known digestibility of the forage sample ("food standard") were included in the test. After $48 \mathrm{~h}$ of incubation, $4 \mathrm{~mL}$ of
$7.4 \%(\mathrm{v} / \mathrm{v})$ hydrochloric acid $(\mathrm{HCl})$ and $2 \mathrm{~mL}$ of $5 \%(\mathrm{w} / \mathrm{v})$ pepsin (1:10,000 diluted) were added to each tube. After $48 \mathrm{~h}$, all samples were vacuum-filtered, then $\operatorname{dried}\left(105^{\circ} \mathrm{C}\right)$, and weighed for calculation of IVDMD.

Estimations of TDN from the organic matter digestibility (OMD) were calculated based on an equation described by Kunkle and Bates (1998), wherein TDN = OM $\{[26.8+0.595($ IVOMD] $/ 100\}$, in which TDN $=$ total digestible nutrients $(\%), \mathrm{OM}=$ organic matter $(\%)$, and IVOMD $=$ in vitro organic matter digestibility $(\%)$.

Total nutrient intake was calculated using nutrient values obtained from the chemical analysis of both concentrate and silage, as $\mathrm{DM} \times(60 \%$ of concentrate nutrient content $+40 \%$ of silage nutrient content), thus providing individual intake of each nutrient, CPI, NDFI, ADFI, and TDNI (Table 2).

Table 1 - Chemical composition of the experimental diet

\begin{tabular}{lcc}
\hline \multirow{2}{*}{ Variable $\left(\mathrm{g} \mathrm{kg}^{-1}\right)$} & \multicolumn{2}{c}{ Diet } \\
\cline { 2 - 3 } & Concentrate & Corn silage \\
\hline Dry matter & 840 & 287 \\
Crude protein & 190 & 838 \\
Neutral detergent fiber & 180 & 451 \\
Acid detergent fiber & 93 & 302 \\
Ash & 69 & 16 \\
Total digestible nutrients & 699 & 605 \\
\hline
\end{tabular}

Table 2 - Average performance and nutrient intake of Holstein calves with different slaughter weights

\begin{tabular}{|c|c|c|c|c|c|c|c|}
\hline \multirow{2}{*}{ Variable } & \multicolumn{4}{|c|}{ Slaughter weight $(\mathrm{kg})$} & \multirow{2}{*}{$\begin{array}{l}\mathrm{CV} \\
(\%)\end{array}$} & \multicolumn{2}{|c|}{ P-value } \\
\hline & 144.6 & 179.8 & 227.6 & 260.5 & & $\mathrm{~L}$ & Q \\
\hline Feedlot (days) & 111.9 & 150.7 & 150.9 & 176.3 & 11.00 & $0.0001^{1}$ & 0.2319 \\
\hline FW (kg) & 144.7 & 180.5 & 226.2 & 256.7 & 3.17 & $0.0001^{2}$ & 0.5370 \\
\hline ADG $(\mathrm{kg})$ & 0.777 & 0.811 & 1.108 & 1.153 & 14.30 & $0.0001^{3}$ & 0.7276 \\
\hline DMI (kg) & 2.36 & 3.38 & 3.53 & 4.51 & 20.16 & $0.0001^{4}$ & 0.8166 \\
\hline DMI (\% LW) & 2.34 & 2.83 & 2.43 & 2.89 & 20.83 & 0.2662 & 0.7806 \\
\hline TDNI (kg) & 2.14 & 3.05 & 3.18 & 4.05 & 19.95 & $0.0001^{5}$ & 0.8117 \\
\hline TDNI (\% LW) & 2.13 & 2.55 & 2.19 & 2.57 & 20.62 & 0.2988 & 0.7899 \\
\hline CPI (kg) & 0.479 & 0.682 & 0.714 & 0.905 & 19.92 & $0.0001^{6}$ & 0.7950 \\
\hline CPI (\% LW) & 0.476 & 0.570 & 0.491 & 0.581 & 20.74 & 0.2996 & 0.7904 \\
\hline NDFI (kg) & 0.937 & 1.336 & 1.382 & 1.785 & 20.52 & $0.0001^{7}$ & 0.8686 \\
\hline NDFI (\% LW) & 0.928 & 1.117 & 0.954 & 1.144 & 20.77 & 0.2790 & 0.8220 \\
\hline ADFI (kg) & 0.572 & 0.815 & 0.859 & 1.084 & 20.25 & $0.0001^{8}$ & 0.7836 \\
\hline ADFI (\% LW) & 0.568 & 0.682 & 0.594 & 0.695 & 20.40 & 0.2785 & 0.7479 \\
\hline $\begin{array}{l}\mathrm{FC}(\mathrm{kg} \mathrm{DM} / \mathrm{kg} \\
\mathrm{ADG})\end{array}$ & 3.11 & 4.14 & 3.16 & 4.03 & 23.51 & 0.3384 & 0.5829 \\
\hline
\end{tabular}

LW - live weight; FW - final weight; ADG - average daily gain; DMI - dry matter intake; TDNI - total digestible nutrient intake; CPI - crude protein intake; NDFI neutral detergent fiber intake; ADFI - acid detergent fiber intake; FC - food conversion; CV - coefficient of variation; $\mathrm{L}$ and $\mathrm{Q}$ - linear and quadratic regression effects, respectively.

${ }^{1}$ Days $=153.09-1.68 \times \mathrm{IW}+0.473 \times \mathrm{SW} ; \mathrm{r}^{2}=0.73$

${ }^{2} \mathrm{FW}=-5.68+0.2837 \times \mathrm{IW}+0.9544 \times \mathrm{SW} ; \mathrm{r}^{2}=0.98$

${ }^{3} \mathrm{ADG}=-0.113+0.0059 \times \mathrm{IW}+0.00362 \times \mathrm{SW} ; \mathrm{r}^{2}=0.63$

${ }^{4} \mathrm{DMI}=0.3214-0.0023 \times \mathrm{IW}+0.0163 \times \mathrm{SW} ; \mathrm{r}^{2}=0.53$

${ }^{5} \mathrm{TDNI}=0.3404-0.0022 \times \mathrm{IW}+0.0145 \times \mathrm{SW} ; \mathrm{r}^{2}=0.53$

${ }^{6} \mathrm{CPI}=0.0812-0.0005 \times \mathrm{IW}+0.00324 \times \mathrm{SW} ; \mathrm{r}^{2}=0.53$.

${ }^{7} \mathrm{NDFI}=0.1161-0.0006 \times \mathrm{IW}+0.00641 \times \mathrm{SW} ; \mathrm{r}^{2}=0.53$

${ }^{8} \mathrm{ADFI}=0.094-0.0007 \times \mathrm{IW}+0.0039 \times \mathrm{SW} ; \mathrm{r}^{2}=0.54$. 
The animals were slaughtered in a slaughterhouse. After slaughter, the two half-carcasses were washed, identified, and weighed before being taken to the cooling chamber to obtain the hot carcass weight. After a cooling period of $24 \mathrm{~h}$ at a temperature of $-2{ }^{\circ} \mathrm{C}$, the carcasses were reweighed to obtain the cold carcass weight and to check the yields of the hot and cold carcasses and losses due to cooling. A section was taken from between the 11th and 12th ribs of the right half of the cold carcass, designated as "HH section", in accordance with the methodology proposed by Hankins and Howe (1946) and adapted by Müller (1987). From that section, the muscle, fat, and bone tissues were physically separated for determination of the total quantity and percentage of these tissues relative to the cold carcass. In that same section, the degree of meat marbling at the height of the 12th rib on the exposed face of the longissimus dorsi muscle was subjectively evaluated and scored based on the methodology described by Müller (1987). The value of the subcutaneous fat thickness was obtained by averaging three observations in the same location.

Sample preparation (extraction and methylation), as well as quantitative and qualitative determination of the lipid fraction and fatty acid composition, were carried out in a laboratory. Extraction of total lipids was performed according to the method described by Bligh and Dyer (1959). Fatty acids were esterified according to the technique described by Hartman and Lake (1973) and analyzed in an Agilent gas chromatograph (HP6890 model) equipped with a flame ionization detector and capillary column (Supelco SP2560; $100 \mathrm{~m} \times 0.25 \mathrm{~mm} \times 0.2 \mu \mathrm{m}$ ). The injector and detector temperatures were maintained at $250{ }^{\circ} \mathrm{C}$ and $280^{\circ} \mathrm{C}$, respectively. The temperature protocol used for the separation of fatty acid esters was $140{ }^{\circ} \mathrm{C}$ for $5 \mathrm{~min}$, then increased by $1.6{ }^{\circ} \mathrm{C} / \mathrm{min}$ to $210{ }^{\circ} \mathrm{C}$ and maintained for $10 \mathrm{~min}$, then increased again by $10^{\circ} \mathrm{C} / \mathrm{min}$ to $240{ }^{\circ} \mathrm{C}$ and maintained for $15 \mathrm{~min}$, for a total run time of $76 \mathrm{~min}$. The carrier gas flow rate $\left(\mathrm{N}_{2}\right)$ was $30 \mathrm{~mL} / \mathrm{min}$, and the injection volume was $1 \mu \mathrm{L}$ with a split ratio of 1:50. Identification of fatty acids was performed by comparing retention time to samples with known standards.

The experimental design was completely randomized, with 23 total animals slaughtered by weight: five animals at $140 \mathrm{~kg}$, six animals at $180 \mathrm{~kg}$, six animals at $220 \mathrm{~kg}$, and six animals at $260 \mathrm{~kg}$. Each animal represented an experimental unit. The mathematical model used in this study, in which the initial live weight of the animals was set as a covariate, was as follows:

$$
\mathrm{Y}_{\mathrm{ijk} \mathrm{k}}=\mu+\mathrm{IW}_{\mathrm{k}}+\mathrm{SW}_{\mathrm{j}}+\mathrm{E}_{\mathrm{ijk} \mathrm{l}} \text {, }
$$

in which $\mathrm{Y}_{\mathrm{ijkl}}=$ dependent variables; $\mu=$ average of all observations; $\mathrm{IW}_{\mathrm{k}}=$ effect of the $k$-th initial live weight; $\mathrm{SW}_{\mathrm{j}}=$ effect of the $j$-th slaughter weight; and $\mathrm{E}_{\mathrm{ijkl}}=$ residual random error.

Data were tested by ANOVA, with polynomial regression analysis using actual slaughter weight performed when statistical differences between slaughter weight categories were detected. Variables were also subjected to Pearson correlation analysis. All statistical analyses were performed with SAS (Statistical Analysis System, version 9.2).

\section{Results}

As expected, the finishing time of calves increased $(\mathrm{P}<0.05)$ with increasing slaughter weight, as did ADG $(\mathrm{P}<0.05)$. Moreover, $\mathrm{ADG}$ affected finishing time of the animals, with time of feedlot averaging 147 days. Animals with higher slaughter weights had a higher absolute DM intake $(\mathrm{P}<0.05)$ according to the weight gain of the animal (Table 2). This occurred concurrently with the absolute intake of nutrients (TDN and CP) and fibrous compounds (NDF and ADF). However, the effect of slaughter weight disappeared when these factors were adjusted as percentages of live weight. The trends for DM intake and weight gain were similar, indicating that feed conversion was not influenced by increasing slaughter weight $(\mathrm{P}>0.05)$.

Slaughter weight had a positive influence $(\mathrm{P}<0.05)$ on weight and cold carcass yield, subcutaneous fat thickness, and absolute weight of the scraps. On the other hand, marbling content and percentage of fat in the carcass were not influenced by higher slaughter weight (Table 3).

Slaughter weight influenced the levels of lipids, CP, and DM (Table 6). Regression analysis revealed that lipid content decreased with increasing animal live weight, whereas CP and DM contents increased. No effect of slaughter weight on ash content was observed. Levels of stearic (C18:0) and behenic (C22:0) acids declined $(\mathrm{P}<0.05)$ with higher slaughter weight (Table 4$)$. The other variables, as well as the sum of saturated fatty acids, were unaffected by slaughter weight. Likewise, oleic (C18:1 cis-9) and linoleic (C18:2 trans-10,cis-12) acids and the sum of unsaturated fatty acids decreased with increasing slaughter weight (Table 5). The sum of omega- 6 and omega-3 fatty acid contents did not vary with slaughter weight $(P>0.05)$. Similarly, the $n-6: n-3$ and polyunsaturated:saturated ratios were unaffected by slaughter weight (Table 6).

R. Bras. Zootec., 47:e20170208, 2018 


\section{Discussion}

The finishing time of animals ranged from 111.9 to 176.3 days and was linearly correlated with increasing slaughter weight, and the increase in average daily weight gain was not sufficient to reduce the finishing time. The increase in average daily weight gain relative to animal live weight observed in this study is generally not seen in bulls and cows (Costa et al., 2002a; Andreotti et al., 2015; Missio et al., 2015). The reduction in daily weight gain typical of older animals is primarily due to the higher energy demands

Table 3 - Average carcass characteristics of Holstein calves with different slaughter weights

\begin{tabular}{|c|c|c|c|c|c|c|c|}
\hline \multirow{2}{*}{ Variable } & \multicolumn{4}{|c|}{ Slaughter weight $(\mathrm{kg})$} & \multirow{2}{*}{ SE } & \multicolumn{2}{|c|}{ P-value } \\
\hline & 144.6 & 179.8 & 227.6 & 260.5 & & $\mathrm{~L}$ & Q \\
\hline $\begin{array}{l}\text { Cold carcass } \\
\text { weight }(\mathrm{kg})\end{array}$ & 67.89 & 87.24 & 111.01 & 128.60 & 2.2 & $0.0001 *$ & 0.8137 \\
\hline $\begin{array}{l}\text { Cold carcass } \\
\text { yield (\%) }\end{array}$ & 46.88 & 48.26 & 49.23 & 49.98 & 0.7 & $0.0024 * *$ & 0.6500 \\
\hline Scraps (kg) & 1.31 & 2.25 & 2.67 & 3.95 & 0.5 & $0.0004 * * *$ & 0.7923 \\
\hline $\begin{array}{l}\text { Scraps (kg/ } \\
100 \mathrm{~kg} \mathrm{SW})\end{array}$ & 0.91 & 1.24 & 1.19 & 1.54 & 0.2 & 0.0525 & 0.9320 \\
\hline $\begin{array}{l}\text { Fat thickness } \\
(\mathrm{mm})\end{array}$ & 0.36 & 0.83 & 1.09 & 1.01 & 0.2 & $0.0374 * * * *$ & 0.2435 \\
\hline $\begin{array}{l}\text { Marbling } \\
\text { (points) }^{1}\end{array}$ & 1.73 & 2.5 & 3.56 & 2.33 & 0.5 & 0.2213 & 0.0648 \\
\hline Fat $(\%)$ & 11.54 & 13.12 & 14.84 & 13.08 & 0.9 & 0.1266 & 0.0811 \\
\hline
\end{tabular}

SW - slaughter weight; IW - initial weight; SE - standard error; L and Q - linear and quadratic regression effects, respectively.

$*$ Cold carcass weight $=-18.36+0.2359 \times \mathrm{IW}+0.5152 \times \mathrm{SW} ; \mathrm{r}^{2}=0.96$.

$* *$ Cold carcass yield $=40.311+0.054 \times \mathrm{IW}+0.0254 \times \mathrm{SW} ; \mathrm{r}^{2}=0.42$.

$* * *$ Scraps $=-1.547-0.0010 \times \mathrm{IW}+0.0208 \times \mathrm{SW} ; \mathrm{r}^{2}=0.47$.

$* * * *$ Fat thickness $=-0.087-0.0028 \times \mathrm{IW}+0.0054 \times \mathrm{SW} ; \mathrm{r}^{2}=0.20$

${ }^{1}$ Marbling: $1-3=$ traces; $4-6=$ mild; $7-9=$ small; 10 to $12=$ medium; $13-15=$ moderate; $16-18=$ abundant.

Table 4 - Quantity of saturated fatty acids in the longissimus lumborum muscle of Holstein calves according to the slaughter weight (expressed in $\mathrm{g} 100 \mathrm{~g}^{-1}$ of lipid)

\begin{tabular}{lcccccccc}
\hline \multirow{2}{*}{ Fatty acid } & \multicolumn{3}{c}{ Slaughter weight $(\mathrm{kg})$} & & \multicolumn{2}{c}{ P-value } \\
\cline { 2 - 4 } \cline { 8 - 9 } & 144.6 & 179.8 & 227.6 & 260.5 & & $\mathrm{~L}$ & $\mathrm{Q}$ \\
\hline C6:0 & 0.08 & 0.06 & 0.07 & 0.09 & 0.02 & 0.7263 & 0.2027 \\
C8:0 & 0.08 & 0.09 & 0.08 & 0.15 & 0.02 & 0.1368 & 0.2851 \\
C10:0 & 0.29 & 0.28 & 0.23 & 0.43 & 0.07 & 0.3118 & 0.1608 \\
C12:0 & 0.41 & 0.43 & 0.35 & 0.46 & 0.06 & 0.8762 & 0.3992 \\
C14:0 & 1.98 & 1.91 & 1.49 & 2.00 & 0.24 & 0.7627 & 0.2375 \\
C15:0 & 0.32 & 0.29 & 0.27 & 0.36 & 0.04 & 0.6447 & 0.1753 \\
C16:0 & 17.53 & 16.99 & 14.73 & 14.42 & 1.29 & 0.0622 & 0.9114 \\
C17:0 & 0.64 & 0.61 & 0.46 & 0.59 & 0.06 & 0.3778 & 0.2479 \\
C18:0 & 16.13 & 14.53 & 11.83 & 12.07 & 1.44 & 0.03971 & 0.5095 \\
C20:0 & 0.15 & 0.15 & 0.14 & 0.14 & 0.01 & 0.4724 & 0.8284 \\
C22:0 & 0.09 & 0.08 & 0.07 & 0.06 & 0.01 & $0.0466^{2}$ & 0.9561 \\
C24:0 & 0.19 & 0.74 & 0.58 & 0.01 & 0.45 & 0.6706 & 0.2240 \\
Saturated & 37.85 & 35.55 & 29.86 & 30.86 & 2.75 & 0.0517 & 0.5351 \\
\hline
\end{tabular}

SW - slaughter weight; IW - initial weight; SE - standard error; L and Q - linear and quadratic regression effects, respectively.

${ }^{1} \mathrm{C} 18: 0=4.3423+0.2831 \times \mathrm{IW}-0.03738 \times \mathrm{SW} ; \mathrm{r}^{2}=0.45$.

${ }^{2} \mathrm{C} 22: 0=0.0431+0.0014 \times \mathrm{IW}-0.00024 \times \mathrm{SW} ; \mathrm{r}^{2}=0.34$. of physiological maintenance and by the greater energy demand related to the composition of the weight gained. Costa et al. (2002a), for instance, in a study involving 14-month-old Red Angus bulls, reported that the percentage of fat in the carcass rose from 21.7 to $26.5 \%$ when slaughter weight increased from 340 to $430 \mathrm{~kg}$. In this case, as adipose

Table 5 - Quantity of unsaturated fatty acids in longissimus lumborum muscle of Holstein calves according to the

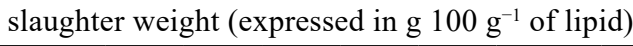

\begin{tabular}{lcccccccc}
\hline \multirow{2}{*}{ Fatty acid } & \multicolumn{3}{c}{ Slaughter weight $(\mathrm{kg})$} & & \multicolumn{2}{c}{ P-value } \\
\cline { 2 - 4 } \cline { 3 - 4 } & 144.6 & 179.8 & 227.6 & 260.5 & & $\mathrm{~L}$ & $\mathrm{Q}$ \\
\hline C14:1n5 & 0.16 & 0.14 & 0.11 & 0.14 & 0.02 & 0.3764 & 0.1987 \\
C16:1n7 & 1.22 & 1.11 & 0.75 & 1.01 & 0.12 & 0.1310 & 0.1520 \\
C18:1n9Trans & 0.24 & 0.26 & 0.22 & 0.21 & 0.03 & 0.3949 & 0.6624 \\
C18:1n9Cis & 20.26 & 20.05 & 15.66 & 16.47 & 1.53 & $0.0403^{1}$ & 0.7178 \\
C18:1n7Trans11 & 1.78 & 1.80 & 1.55 & 1.71 & 0.17 & 0.5111 & 0.6509 \\
C18:2n6Cis9 & 8.33 & 8.30 & 7.25 & 6.62 & 0.76 & 0.0808 & 0.6990 \\
C18:2c9Trans11 & 0.21 & 0.23 & 0.17 & 0.29 & 0.04 & 0.5066 & 0.2918 \\
C18:2Trans10Cis12 & 0.019 & 0.016 & 0.012 & 0.010 & 0.002 & $0.0162^{2}$ & 0.7476 \\
C18:3n6 & 0.08 & 0.07 & 0.09 & 0.05 & 0.01 & 0.3214 & 0.2585 \\
C18:3n3 & 0.81 & 0.75 & 0.70 & 0.73 & 0.07 & 0.4036 & 0.4887 \\
C20:1n9Cis11 & 0.02 & 0.02 & 0.01 & 0.01 & 0.002 & 0.0677 & 0.9693 \\
C20:2n6 & 0.09 & 0.07 & 0.06 & 0.06 & 0.01 & 0.1247 & 0.5380 \\
C20:3n6 & 0.66 & 0.49 & 0.68 & 0.35 & 0.15 & 0.3677 & 0.5851 \\
C20:4n6 & 2.75 & 1.97 & 2.44 & 1.32 & 0.52 & 0.1608 & 0.7213 \\
C20:5n3 & 0.16 & 0.15 & 0.21 & 0.15 & 0.04 & 0.8690 & 0.5940 \\
C22:6n3 & 0.07 & 0.03 & 0.04 & 0.01 & 0.02 & 0.1810 & 0.9949 \\
C24:1n9 & 0.08 & 0.08 & 0.06 & 0.04 & 0.02 & 0.0775 & 0.5341 \\
Unsaturated & 36.95 & 35.55 & 30.01 & 29.19 & 3.41 & $0.0416^{3}$ & 0.9025 \\
Polyunsaturated & 13.19 & 12.09 & 11.65 & 9.59 & 1.39 & 0.0962 & 0.7185 \\
\hline
\end{tabular}

SE - standard error; L and Q - linear and quadratic regression effects, respectively; IW - initial weight; SW - slaughter weight.

${ }^{1} \mathrm{C} 18: 1 \mathrm{n} 9 \mathrm{C}$ is $=10.1554+0.2742 \times \mathrm{IW}-0.04123 \times \mathrm{SW} ; \mathrm{r}^{2}=0.40$.

${ }^{2} \mathrm{C} 18: 2$ Trans10Cis $12=0.02576+0.000069 \times \mathrm{IW}-0.000077 \times \mathrm{SW} ; \mathrm{r}^{2}=0.28$.

${ }^{3}$ Unsaturated $=18.615+0.493 \times \mathrm{IW}-0.074 \times \mathrm{SW} ; \mathrm{r}^{2}=0.40$.

Table 6 - Percentage content of lipids, crude protein, dry matter, and ash and sum of omega-3 fatty acids, omega-6, $\mathrm{n}-3: \mathrm{n}-6$, and polyunsaturated:saturated ratio in the longissimus lumborum muscle of Holstein calves with different slaughter weights

\begin{tabular}{lcccccccc}
\hline \multirow{2}{*}{ Total fatty acid } & \multicolumn{9}{c}{ Slaughter weight $(\mathrm{kg})$} & & \multicolumn{2}{c}{ P-value } \\
\cline { 2 - 4 } \cline { 8 - 9 } & 144.6 & 179.8 & 227.6 & 260.5 & & $\mathrm{~L}$ & $\mathrm{Q}$ \\
\hline Lipids & 0.82 & 0.79 & 0.66 & 0.66 & 0.06 & $0.0364^{*}$ & 0.7787 \\
Crude protein & 19.3 & 20.0 & 21.0 & 20.9 & 0.35 & $0.0049^{1}$ & 0.2580 \\
Dry matter & 21.3 & 21.9 & 22.9 & 22.7 & 0.38 & $0.0130^{2}$ & 0.2423 \\
Ash & 1.03 & 1.04 & 1.16 & 1.05 & 0.04 & 0.4265 & 0.1774 \\
Omega-6 (n-6) & 3.59 & 2.60 & 3.27 & 1.78 & 0.67 & 0.1851 & 0.6854 \\
Omega-3 (n-3) & 1.04 & 0.94 & 0.95 & 0.90 & 0.10 & 0.3992 & 0.8026 \\
n-6:n-3 & 3.33 & 2.82 & 3.31 & 1.99 & 0.56 & 0.2278 & 0.4660 \\
Polyunsaturated: & 0.34 & 0.37 & 0.40 & 0.31 & 0.02 & 0.5838 & $0.0384 * *$ \\
saturated & & & & & & & & \\
\hline
\end{tabular}

SE - standard error; L and Q - linear and quadratic regression effects, respectively; IW - initial weight; SW - slaughter weight.

$*$ Lipids $=0.390+0.0112 \times \mathrm{IW}-0.00158 \times \mathrm{SW} ; \mathrm{r}^{2}=0.43$.

** Polyunsaturated:saturated ratio $=-0.391+0.00089 \times \mathrm{IW}+0.00746 \times \mathrm{SW}$ $-0.000019 \times \mathrm{SW}^{2} ; \mathrm{r}^{2}=0.25$.

${ }^{1}$ Crude protein $=18.30-0.0143 \times \mathrm{IW}+0.0143 \times \mathrm{SW} ; \mathrm{r}^{2}=0.36$

${ }^{2}$ Dry matter $=19.91-0.0052 \times \mathrm{IW}+0.0133 \times \mathrm{SW} ; \mathrm{r}^{2}=0.30$. 
tissue contains higher concentrations of energy than muscle tissue, the provided diet failed to supply the amount of energy needed to maintain the same rate of ADG. In the present study, the highest slaughter weight was $260 \mathrm{~kg}$ and maximum estimated carcass fat only reached $13.5 \%$, a level too low to affect animal performance (Santos et al., 2013). In addition, the observed weight gain was similar to that previously reported (Montoro et al. 2013). Thus, our results demonstrate the potential that Holstein calves have for beef production at a young age.

The increase in animal performance with the increase in slaughter weight is due to the increase in DM and nutrient intake of the animals and a corresponding rise in their ingestive capacity. Some researchers (Costa et al., 2002a; Missio et al., 2015) reported a reduction in DM intake with increasing slaughter weight, and NRC (2000) reported that reductions in feed intake as live weight increases is associated with leptin activity and indicates the presence of higher body fat deposition; however, the animals tested in those studies were slaughtered at a later degree of finishing, unlike in the present study. We observed that differences in daily weight gain ceased to exist when expressed as a percentage of live weight, demonstrating that the increasing intake was due to the larger size of the animals. Even lighter animals displayed efficient intakes of DM and nutrients. Feed intake is directly linked to ingestive capacity of the animal and its potential for growth; thus, animals with greater potential for growth (and higher nutritional demand), such as the Holstein breed, tend to have higher levels of feed intake compared with other breeds (Stoffel et al., 2015). Animals with a live weight below $150 \mathrm{~kg}$ have higher intake rates, according to estimates (NRC, 2000). Holstein calves with a live weight below $150 \mathrm{~kg}$ that are fed diets containing $>60 \%$ of TDN consume an amount of food equal to approximately $4 \%$ of their live weight.

The TDNI, CPI, NDFI, and ADFI are linked in the same way as DM intake is, to increasing slaughter weight. The NRC (2001) stated that, in dairy calves, energy intake varies from 1.37 to $2.72 \mathrm{~kg}$ of TDN in animals weighing 40 $150 \mathrm{~kg}$, and around $2.14 \mathrm{~kg}$ for animals weighing $\sim 144 \mathrm{~kg}$. We observed a high rate of intake of TDN, ranging from 2.14 to $4.05 \mathrm{~kg}$, which accounted for the increase in ADG. According to the NRC (2001), for developing calves aged 3-6 months, diets consisting of $23 \%$ NDF are necessary to maintain rumen microbial balance. In our study, dietary NDF was approximately $28.8 \%$ higher than recommended levels, yet, according to the NRC (2001), NDFI values of $1-1.2 \%$ of live weight are ideal for the growth phase and, if exceeded, would cause intake restriction due to filling of the rumen-reticulum. In our case, intake values ranged from
0.928 to $1.114 \%$ of live weight, which were close to the ideal. Confirming that, in this study, the supply of nutrients met the growth requirements and meat production of calves.

Among cattle, low carcass yield is a shortcoming unique to dairy breeds. According to Fernandes et al. (2004), animals selected for meat production generally have carcass yields $7 \%$ higher than those of dairy breeds. However, carcass production improved with the increase in carcass yield, because the vital organs, and not the initial stage of life of the animal, represent a greater proportion. Growth rates of muscle tissue, and especially adipose tissue, increase as the animal ages, with the internal organs comprising a lower proportion of empty body weight in older animals. Increasing amounts of adipose tissue may be observed via the greater thickness of subcutaneous fat. Numerous previous studies have reported that carcass fat thickness increases when the slaughter weight of animals is higher (Costa et al., 2002b; Arboitte et al., 2004).

The amount and composition of fatty acids greatly influence the quantity of both body and intramuscular fat (De Smet et al., 2004). Differences in maturity, age, and/ or live weight at slaughter contribute even more to the differences in the amount of fat. Growing and fattening stages are characterized first by increased deposition of fat in the subcutaneous layer, then by increased deposition in the intramuscular layer (Vernon and Flint, 1988). In our study, lipid content decreased with increasing slaughter weight, despite the little variation in marbling content, as was also noted by Santos et al. (2013), who studied the same breed. Stearic (C18:0) and behenic (C22:0) acids both decreased with increasing live weight. Stearic fatty and palmitic acids are among the most abundant fatty acids in beef. The decrease observed in these fatty acids may be related to the reduction of ether extract as the slaughter weight decreased (Scollan et al., 2006). The correlations observed between ether extract content and stearic and behenic acids were significant $(\mathrm{P}<0.01 ; \mathrm{r}=0.95$ and 0.72 , respectively). However, the variability in these fatty acids was not sufficient to influence the sum of saturated fatty acids.

We expected to find lower levels of saturated fatty acids in the heavier animals, due to greater concentrate intake. As dietary energy levels increase, the content of monounsaturated fatty acids increase, to the detriment of saturated fatty acids (Toma et al., 2015). Likewise, Nogalski et al. (2014) reported that slaughter weight had no effect on the sum of saturated fatty acids when comparing animals whose slaughter weights ranged from 450 to $600 \mathrm{~kg}$

Kuss et al. (2007) investigated culled cows and reported a negative association $(\mathrm{r}=-0.61 ; \mathrm{P}<0.01)$ between marbling and the fraction of saturated fats. However, the 
differences in ages and weights of the animals included in the present study were not sufficient to affect the amount of marbling, as was also noted by Santos et al. (2013).

Unlike what was observed in previous studies (Xie et al., 1996; Kuss et al., 2007), oleic acid decreased with increasing slaughter weight and, consequently, with increasing feedlot time. De Smet et al. (2004) attributed the lower levels of oleic acid in bulls to the effects of sex hormones in enzymatic systems that control the transformation of other fatty acids into oleic acid, such as $\Delta 9$-desaturase. This may have happened in our study as well because the heavier animals were closer to puberty. Oleic acid (C18:1 n-9) is considered as a desirable fatty acid in meat for its role in reducing blood cholesterol levels (hypocholesterolemic effect), and its prevalence in meat is primarily associated with the type of diet, feeding time, genetic group, and age of the animal (De Smet et al., 2004; Smith et al., 2009; Daley et al., 2010).

Among the CLA identified, only C18:2 trans-10,cis-12 was negatively correlated with slaughter weight. However, the total amount of CLA was too low to confer any benefits to human health. According to Kim et al. (2016), trans-10,cis-12 and cis-9,trans-11 are the most abundant of all CLA isomers. In their review of the benefits of CLA on human health, they reported that consumption of $3 \mathrm{~g}$ per day of CLA has the potential to reduce colorectal cancer (although consumption should be limited to $\sim 6 \mathrm{~g}$ CLA, given that there are no studies on the potential harmful effects of excess consumption of this fatty acid). Reductions in oleic acid and CLA trans-10,cis-12 contributed to the lower levels of unsaturated fat in the meat of the heaviest animals. The increase of unsaturated fatty acid levels in animals with higher slaughter weight (Kuss et al., 2007) is often associated with increased marbling in meat, but we found that the heaviest animals had lower lipid contents and exhibited little variation in marbling (Santos et al., 2013), most likely due to the young age of the animals (6-8 months). Moreover, there is the fact that the heavier animals, and thus the older ones, may have been approaching puberty, which might have resulted in a greater deposition of lean tissue and, thus, did not produce the expected increase in meat lipid content.

Despite the fact that slaughter weight had no effect on the $n-3, n-6$, and n-6:n-3 ratio of total fatty acids, these values remained below the maximum recommended (4:1) for human consumption (United Kingdom, 1994). The higher levels of n-3 relative to $n-6$ fatty acids promote a dietary balance because $n-6$ fatty acids have been linked to inflammation and tumors, whereas n-3 fatty acids act in the opposite manner (Simopoulos, 2002).

\section{Conclusions}

Rising the slaughter weight of Holstein calves from 144 to $260 \mathrm{~kg}$ improves the performance of these animals, mainly as a result of a concomitant increase in intake capacity. However, this increase in slaughter weight does not change the fatty acid composition of the meat.

\section{Acknowledgments}

We thank the Conselho Nacional de Desenvolvimento Científico e Tecnológico (CNPq - Process: 470988/2010-0) and the Fundação Araucária (CP 14-2009 - Protocol 17505) for the financial support to the project. This study was financed in part by the Coordenação de Aperfeiçoamento de Pessoal de Nível Superior - Brasil (CAPES) - Finance Code 001.

\section{References}

Andreotti, C. C.; Gusman J. A. P.; Ramos, T. R.; Barcellos, V. C.; Guerrero, A. and Prado, I. N. 2015. Slaughter weight did not alter carcass characteristics and meat quality of crossbred heifers supplemented and finished in a pasture system. Acta Scientiarum Animal Sciences 37:173-179. https://doi.org/10.4025/ actascianimsci.v37i2.25847

Arboitte, M. Z.; Restle, J.; Alves Filho, D. C.; Pascoal, L. L.; Pacheco, P. S. and Soccal, D. C. 2004. Características da carcaça de novilhos 5/8 Nelore-3/8 Charolês abatidos em diferentes estádios de desenvolvimento. Revista Brasileira de Zootecnia 33:969-977. https://doi.org/10.1590/S1516-35982004000400017

AOAC - Association of Official Analytical Chemists. 1995. Official methods of analysis. 16th ed. AOAC, Arlington, VA.

Bligh, E. G. and Dyer, W. J. 1959. A rapid method of total lipid extraction and purification. Canadian Journal of Biochemistry and Physiology 37:911-917.

Costa, E. C.; Restle, J.; Pascoal, L. L.; Vaz, F. N.; Alves Filho, D. C. and Arboitte, M. Z. 2002a. Desempenho de novilhos Red Angus superprecoces, confinados e abatidos com diferentes pesos. Revista Brasileira de Zootecnia 31:129-138. https://doi. org/10.1590/S1516-35982002000100015

Costa, E. C.; Restle, J.; Vaz, F. N.; Alves Filho, D. C.; Bernardes, R. A. L. C. and Kuss, F. 2002b. Características da carcaça de novilhos Red Angus superprecoces abatidos com diferentes pesos. Revista Brasileira de Zootecnia 31:119-128. https://doi.org/10.1590/ S1516-35982002000100014

Daley, C. A.; Abbot, A.; Doyle, P. S.; Nader, G. A. and Larson, S. 2010. A review of fatty acid profiles and antioxidant content in grass-fed and grain-fed beef. Nutrition Journal 9:10. https://doi. org/10.1186/1475-2891-9-10

De Smet, S.; Raes, K. and Demeyer, D. 2004. Meat fatty acid composition as affected by fatness and genetic factors: a review. Animal Research 53:81-98. https://doi.org/10.1051/ animres:2004003

Domaradzki, P.; Stanek, P.; Litwińczuk, Z.; Skałecki, P. and Florek, M. 2017. Slaughter value and meat quality of suckler calves: a review. Meat Science 134:135-149. https://doi.org/10.1016/j. meatsci.2017.07.026

Fernandes, H. J.; Paulino, M. F.; Martins, R. G. R.; Valadares Filho, S. C.; Torres, R. A.; Paiva, L. M. and Silva, A. T. S. 2004. Composição 
corporal de garrotes inteiros de três grupos genéticos nas fases de recria e terminação. Revista Brasileira de Zootecnia 33:1581-1590. https://doi.org/10.1590/S1516-35982004000600026

Griinari, J. M. and Bauman, D. E. 2001. Production of low fat milk by diet induced milk fat depression. Advances in Dairy Technology 13:198-212.

Hankins, O. G. and Howe, P. E. 1946. Estimation of the composition of beef carcasses and cuts. Technical Bulletin-USDA, 926. United Sates Department of Agriculture, Washington, D.C.

Hartman, L. and Lake, R. C. A. 1973. Rapid preparation of fatty acid methyl esters from lipids. Laboratory Practice 22:475-476.

Kim, J. H.; Kim, Y.; Kim, Y. J. and Park, Y. 2016. Conjugated linoleic acid: potential health benefits as a functional food ingredient. Annual Review of Food Science and Technology 7:221-244. https://doi.org/10.1146/annurev-food-041715-033028

Kunkle, W. E. and Bates, D. B. 1998. Evaluating feed purchasing options: energy, protein, and mineral supplements. p.59-70. In: Proceedings of the Florida Beef Cattle Short Course. Gainesville.

Kuss, F.; Restle, J.; Kosloski, G. V.; Deschamps, F.; Moletta, J. L.; Santos, A. P. and Fiamoncini, J. 2007. Perfil de ácidos graxos da gordura intramuscular da carne de vacas de descarte de diferentes grupos genéticos terminadas em confinamento, abatidas com distintos pesos. Ciência Rural 37:815-820. https://doi. org/10.1590/S0103-84782007000300033

Lopez-Campos, O.; Aalhus, J. L.; Okine, E. K.; Baron, V. S. and Basarab, J. A. 2013. Effects of calf- and yearling-fed beef production systems and growth promotants on production and profitability. Canadian Journal of Animal Science 93:171-184. https://doi.org/10.4141/cjas2012-035

Missio, R. L.; Restle, J.; Moletta, J. L.; Kuss, F.; Neiva, J. N. M.; Elejalde, D. A. G.; Moura, I. C. F.; Prado, I. N. and Miotto, F. R. C. 2015. Slaughter weights on animal performance, carcass commercial cuts and meat characteristics of cull cows. SeminaCiências Agrárias 36:3827-3841.

Montoro, C.; Miller-Cushon, E. K.; DeVries, T. J. and Bach, A. 2013. Effect of physical form of forage on performance, feeding behavior, and digestibility of Holstein calves. Journal of Dairy Science 96:1117-1124. https://doi.org/10.3168/jds.2012-5731

Müller, L. 1987. Normas para avaliação de carcaças e concurso de carcaça de novilhos. 2a ed. Imprensa Universitária, Santa Maria.

NRC - National Research Council. 2000. Nutrient requirements of beef cattle. 7th ed. National Academic Press, Washington, DC.

NRC - National Research Council. 2001. Nutrient requirements of dairy cattle. 7th rev. ed. National Academic Press, Washington, DC.

Nogalski, Z.; Wielgosz-Groth, Z.; Purwin, C.; Sobczuk-Szul, M.; Mochol, M.; Pogorzelska-Przybytek, P. and Winarski, R. 2014. Effect of slaughter weight on the carcass value of young crossbred ("Polish Holstein Friesian Limousin") steers and bulls. Chilean Journal of Agricultural Research 74:59-66. https:// doi.org/10.4067/S0718-58392014000100010

Sañudo, C.; Macie, E. S.; Olleta, J. L.; Villarroel, M.; Panea, B.; Albertí, P. 2004. The effects of slaughter weight, breed type and ageing time on beef meat quality using two different texture devices. Meat Science 66:925-932. https://doi.org/10.1016/j. meatsci.2003.08.005

Santos, P. V.; Paris, W.; Menezes, L. F. G.; Vonz, D.; Silveira, M. F. and Tubin, J. 2013. Carcass physical composition and meat quality of Holtein calves, terminated in different finishing and slaughter weights. Ciência e Agrotecnologia 37:433-450.

Scollan, N.; Hocquette, J. F.; Nuernberg, K.; Dannenberger, D.; Richardson, I. and Moloney, A. 2006. Innovations in beef production systems that enhance the nutritional and health value of beef lipids and their relationship with meat quality. Meat Science 74:17-33. https://doi.org/10.1016/j.meatsci.2006.05.002

Simopoulos, A. P. 2002. The importance of the ratio of omega-6/ omega-3 essential fatty acids. Biomedicine \& Pharmacotherapuy 56:365-379. https://doi.org/10.1016/S0753-3322(02)00253-6

Smith, S. B.; Gill, C. A.; Lunt, D. K. and Brooks, M. A. 2009. Regulation of fat and fatty acid composition in beef cattle. AsianAustralasian Journal of Animal Sciences 22:1225-1233.

Sobczuk-Szul, M.; Wroński, M.; Wielgosz-Groth, Z.; Mochol, M.; Rzemieniewski, A.; Nogalski, Z.; Przybyłek, P. P. and Purwin, C. 2013. The effect of slaughter season on the fatty acid profile in four types of fat deposits in crossbred beef bulls Asian-Australasian Journal of Animal Sciences 26:275-281.

Stoffel, C. M.; Crump, P. M. and Armentano, L. E. 2015. Effect of dietary fatty acid supplements, varying in fatty acid composition, on milk fat secretion in dairy cattle fed diets supplemented to less than 3\% total fatty acids. Journal of Dairy Science 98:431-442. https://doi.org/10.3168/jds.2014-8328

Tilley, J. M. A. and Terry, R. A. A. 1963. A two-stage technique for the in vitro digestion of forage crops. Journal of the British Grassland Society 18:104-111. https://doi.org/10.1111/ j.1365-2494.1963.tb00335.x

Toma, S.; Dragomir, C.; Habeanu, M.; Ropota, M.; Cismileanu, A. and Grosu, H. 2015. Effects of replacing sunflower meal with camelina meal on dairy cows performances. Archiva Zootechnica 18:85-94.

United Kingdom. Department of Health. 1994. Nutritional aspects of cardiovascular disease: report on health and social subjects. HMSO, London.

Van Soest, P. J.; Robertson, J. B. and Lewis, B. A. 1991. Methods for dietary fiber, neutral detergent fiber, and nonstarch polyssacharides in relation to animal nutrition. Journal of Dairy Science 74:3583-3590. https://doi.org/10.3168/jds.S0022-0302(91)78551-2

Vernon, R. G. and Flint, D. F. 1988. Lipid metabolism in farm animals. Proceedings Nutrition Society 47:287-293.

Xie, Y. R.; Busboom, J. R.; Gaskins, C. T.; Johnson, K. A.; Reeves, J. J.; Wright, R. W. and Cronrath, J. D. 1996. Effects of breed and sire on carcass characteristics and fatty acid profiles of crossbred Wagyu and Angus steers. Meat Science 43:167-177. https://doi.org/10.1016/0309-1740(96)84588-8

Wood, J. D.; Enser, M.; Fisher, A. V.; Nute, G. R.; Sheard, P. R.; Richardson, R. I.; Hughes, S. I. and Whittington, F. M. 2008. Fat deposition, fatty acid composition and meat quality: a review. Meat Science 78:343-358. https://doi.org/10.1016/j. meatsci.2007.07.019 